\title{
Isolation and Characterization of Partial cDNA of Sucrose Synthase Putative Gene in Palmyra Palm (Borassus flabellifer)
}

\author{
Fainmarinat Inabuy, Adi Pancoro
}

Research Center for Biotechnology, Institute Technology Bandung, J1. Ganesha no.10 Bandung, Indonesia- 40132.email: fimaluvbio@yahoo.com

\begin{abstract}
Intensification of biofuel resources is urgently needed considering decreased availability of world's fossil fuel. Palmyra palm (Borassus flabellifer) is highly potential to be developed as bioethanol source regarding the high sucrose content in its nira. It was observed that nira produced in dry season is sweeter than that in rainy season, which presumed to be influenced by a difference in expression level of sucrose-related genes during the two seasons. Study of Sucrose Synthase (SUS) gene of palmyra are therefore required prior to study of the gene expression. Palmyra SUS gene sequence is currently unavailable in GenBank, thereby pair of primers was designed from highly conserved region of SUS proteins among monocots. A 1866 bp partial cDNA fragment of SUS putative gene has been succesfully isolated from RNA of the young leaves of $B$. flabellifer. BLASTn and BLASTp aligments showed that either BfSUS cDNA or BfSUS polypeptide has high similarity with SUS cDNA and proteins from diverse plant species with the highest similarity shown by Tulipa gesneriana. The phylogenetic tree showed that SUS protein sequences of monocot species were distinctively grouped and splitted from those of dicot species. The BfSUS was clustered in monocot group, although not specifically grouped with particular monocot species. Nevertheless, B. flabellifer showed nearest genetic distance with Tulipa gesneriana and Oncidium cv.'Goldiana'. Characterization of BfSUS polypeptide using Geneious 4.6.2 indicated the presence of sucrose synthase (SUS) and glycosyl transferase (GT) domains, four putative UDP-glucose binding pockets within the GT domain, and a calciumdependent Ser/Thr protein kinase binding site within the SUS domain. These domains and motifs are highly conserved in SUS proteins across plant species, confirming that the cDNA fragment obtained in this study is very likely cDNA encodes sucrose synthase in B. flabellifer.
\end{abstract}

Keywords: Borassus flabellifer, nira, sucrose, sucrose synthase, SUS domain, GT domain, Palmyra palm.

\section{INTRODUCTION}

Palmyra (Borassus flabellifer) is a palmae species with high potency to be developed as a source of bioethanol. The plant is typically grown in dry areas in strictly seasonal tropical or subtropical climate. The palmyra palm is known to be very adaptive in dry areas with only 500-900 mm annual rainfall (Flach and Rumawas, 1996). The main product of palmyra is the sweet liquid produced from its inflorescence, called nira, or locally known as tuak (Fox, 1977). The nira of palmyra palm contains $17-20 \%$ dry matters comprises of sucrose, amino acids, proteins, vitamins, and other essential minerals. Sucrose $\left(\mathrm{C}_{6} \mathrm{H}_{12} \mathrm{O}_{6}\right)$ that constitutes $13-18 \%$ per liter nira is the principal material in the production of bioethanol through the process of fermentation. It was observed in East Nusa Tenggara, particularly in Timor and Rote islands, that nira tapping is more 
preferable in dry season rather than in rainy season. Beside the safety reason, it is probably because palmyra nira in dry season is sweeter than in rainy season. It becomes interesting to study whether this phenomena is solely caused by high level of water contained in the nira, by a higher rate of photosynthesis occurred in dry season, or it has something related with sucrose genes expression level. A preliminary study on sucrose related gene expressed in palmyra palm is therefore needed to answer the question.

Sucrose is the most important plant disaccharide; it is the principle form by which photosynthetic product is transported throughout plant tissues from the source photosynthetic tissue to the sink non-photosynthetic tissues (Bush, 1999). This disaccharide consists of one molecule of glucose and one molecule of fructose that is bounded by a glycosidic bond (Lodish et al., 1999). Many enzymes involved in metabolism of sucrose. The closest related enzymes are sucrose-synthase (SUS: EC 2.4.1.13), sucrose phosphate synthase (SPS: EC 2.4.1.14), sucrose-6-phosphatephosphatase (SPPase: EC 3.1.3.24), and invertase (EC 3.2.1.26). The reversible and irreversible reactions of sucrose hydrolysis are catalyzed, respectively, by SUS and invertase. The biosynthesis of sucrose is catalyzed by the sequential action of SPS and SPPase (Winter and Huber, 2000). Sucrose can be synthesized from hexose monophosphates by SUS or SPS. In the case of SUS, the in vivo sucrose concentrations are always much higher than fructose or UDPglucose, resulting in reaction that is essentially always towards the direction of sucrose cleavage. Invertase, on the other hand, only catalyzes the cleavage of sucrose into glucose and fructose.

All enzymes catalyze transfer of sugar moieties from activated donor molecules to specific acceptor molecules by forming glycosidic bonds are classified in the glucosyltranferase (GT) family of enzyme. Sucrose synthase (EC 2.4.1.13) is a key enzyme involved in sucrose metabolism, included in the GT4 family regards to its role in transferring the glucose from UDPglucose to fructose molecule to form sucrose or, in reverse, hydrolyze the sucrose into glucose and fructose. SUS enzyme plays significant role in food storage of many plants, either in the form of starch or sugar (Baud et al., 2004). SUS was shown to control the mobilization of sucrose into various pathways that important for the metabolic, structural, and storage functions of the plant cell. Phloem-loading, a process by which sucrose is transported from photosynthetic to nonphotosynthetic tissues, is facilitated by SUS. Inhibition of SUS-encoding genes had shown significant reduction in sucrose import capacity of floem tissues, thereby causing less sucrose content in tomato fruit (D'Aoust et al., 1999). Conversion of sucrose to UDP-glucose that is catalyzed by SUS provides substrate for cell wall biosynthesis and starch synthesis in plant storage organs (Sun et al., 1992; Zrenner et al., 1995; Dejardin et al., 1997; Hendrik, 1990). SUS activity also associated with development of nodules in legume plants and in regulation of apical meristem function (Craig et al., 1999). Studies on SUS-encoding genes in many plant species revealed that in vitro environmental conditions, such as light, temperature, and water availability have a significant influence on the expression of SUS-encoding genes. Palmyra (B. flabellifer) which has higher sugar content in dry season than in wet season, probably reflects a likewise relation.

SUS genes have been isolated from various starch and sugar-storing plants, such as citrus (CitSUSA and CitSUS2) (Komatsu et al., 2002), sugarcane (Kumar et al., 2007), rice (Wang et al., 1992), maize (Susl and Shl gene) (McCarty et al., 1986), wheat (Marana et al., 1988), cotton (Ruan et al., 2003), tomato (Sun et al., 1992), and potato (Zrenner et al., 1995). The enzyme is found in all plant tissues but is highly expressed particularly in sink tissues (Baud et al., 2004). According to those studies, the full length SUS gene has in average $4970 \mathrm{bp}$ length, while its cDNA length is only about half of it, ranging from 2400 to $2500 \mathrm{bp}$. This research was aimed to study the characteristic of SUS gene in B. flabellifer. A comprehensive knowledge of the SUS gene characteristics is an initial requirement to study its expression level, and further to conduct manipulation or control of those genes, which enables efforts to enhance the productivity of $B$. flabellifer as a potential source of sugar and bioethanol. 


\section{RESULTS AND DISCUSSION}

\section{RNA Isolation from Borassus flabellifer}

Total RNA of B. flabellifer was isolated from the young leaves of 35-40 years old-plants. Young leaves was chosen as it was reported that SUS genes are commonly expressed in newly developed tissues that require supply of either sucrose or sucrose derived-compounds (Kumar et al., 2007). The results of five methods tested for RNA isolation from B. flabellifer is summarized in Table 1. The modified method of Apt et al. (1995) resulted in good quality of RNA although the purity and quantity were rather low. The RNA isolation was best accomplished by using TRI $_{\text {ZoL }}{ }^{\circledR}$ Reagent (Invitrogen). The reagent, a mono-phasic solution composed of phenol and guanidine isothiocyanate, is an improvement to the single-step RNA isolation method developed by Chomczynski and Sacchi (1987). This method successfully generated two distinct bands of 18s and 28 s ribosomal RNA that were clearly occurred in $1 \%$ gel electrophoresis (Figure 1), which indicated a good RNA quality. The RNA yield was relatively high, $1600 \mu \mathrm{g} / \mathrm{ml}$, with low protein contamination as shown by the ratio 1.62 . We noted that the success in obtaining high RNA yield from Borassus leaves is greatly determined by the finest powder that could be recovered from the leaves tissue.

\section{Reverse Transcription- PCR}

A total cDNA from the young leaves of $B$. flabellifer were obtained by cDNA synthesis. They then used as template for the next PCR reaction. The annealing of SUS-spesific primers to the target cDNA were best achieved in temperature $52^{\circ} \mathrm{C}$. As well, $2 \mathrm{mM}$ of $\mathrm{Mg}^{2+}$ and $1.5 \mu \mathrm{g} / 50 \mu \mathrm{l}$ of template cDNA were found to be the most suitable concentration for the PCR mix. Total 30 cycles of amplification using the gene specific primers, SSFw and SSRv, has successfully produced a single fragment of $1866 \mathrm{bp}$ that was detected in 1\% agarose gel (Figure 2). According to the expected product size, this $1866 \mathrm{bp}$ fragment was predicted as the target fragment of the SUS gene.

\section{Cloning of SUS Putative Gene and Transformation of $E$. coli}

Prior to sequencing reaction, the SUS putative fragment is purified from the agarose gel and then cloned into a plasmid vector, pGEM $^{\circledR}$-T easy (PROMEGA), which then delivered to E. coli strain DH5 $\alpha$. E. coli cells that had been transformed were able to grow in the ampicilincontaining medium. Transformed cells containing SUS gene fragment were selected by bluewhite screening method. Transformation of $E$. coli strain DH5 $\alpha$ with pGEM $^{\circledR}-\mathrm{T}$ containing SUS fragment resulted in blue and white colonies growth on the ampicillin contained-LB media.

\section{Plasmid Isolation and Confirmation of Gene Insertion}

Plasmid isolation from the $E$. coli white colony and subsequent restriction cut using particular restriction enzymes are purposed to confirm the presence of the SUS gene fragment within the plasmid of E. coli. When cut with EcoRI, the plasmid produced two unexpected fragments, \pm $1300 \mathrm{bp}$ and $\pm 500 \mathrm{bp}$, instead of $1866 \mathrm{bp}$ (Figure 3a). It was presumed that the SUS fragment of $B$. flabellifer has an EcoRI restriction site within its sequence, thereby produced shorter fragment than expected. It was found later that the sequence of SUS gene of B. flabellifer does have the recognition site for EcoRI. The plasmid was then cut with another endonuclease enzyme, NotI. As expected, cutting with NotI generated a single $1866 \mathrm{bp}$ fragment (Figure 3b). This result indicated that the SUS gene fragment had been successfully inserted into the $\mathrm{pGEM}^{\circledR} \mathrm{T}$ easy plasmid.

PCR screening with SP6 and T7 primers was further conducted to prove the presence of SUS fragment within the multiple cloning sequence (MCS) region in the plasmid. Those two primers 
flank the MCS region in the pGEM ${ }^{\circledR}-T$ easy plasmid. As expected, a \pm 1995 bp fragment was occurred (Figure $3 \mathrm{c}$ ). This length corresponds to the length of the SUS fragment, $\pm 1866 \mathrm{bp}$, plus 129 bp lengths of the SP6 and T7 MCS region.

\section{Sequencing and Characterization of SUS Putative Gene and Polypeptide}

Two steps of sequencing were required since SUS putative fragment of $B$. flabellifer, further stated as BfSUS, is relatively long for a single reading by the sequencer system. The SP6 and T7 primers were used in the former sequencing, followed by specific internal primers to read the gap sequence within the fragment. The later primers were designed from the read of the former sequence. Using Geneious 4.6.2 program, an overlapped reading occurred from those two steps of sequencing, thus finally assembly the whole sequence of the BfSUS putative gene fragment. The assembled BfSUS fragment was trimmed from pGEM $^{\circledR} \mathrm{T}$ vector region by using VecScreen program (www.ncbi.nlm.nih.gov), followed by determination of SSFw and SSRv primers annealing region. The final construction of BfSUS partial gene, which total length is $1866 \mathrm{bp}$, was successfully obtained (Figure 4).

The sequence of BfSUS putative gene was first analyzed by BLASTn program (Altschul et al., 1997) to figure out the similarity level of BfSUS putative gene with other SUS gene sequences recorded in the GenBank. The percentage of identical sites and query coverage indicated that BfSUS putative gene shares quite high similarity, $70.8 \%-80.6 \%$, with $S U S$ genes from various monocots. Thus, confirming that the isolated $1866 \mathrm{bp} B f S U S$ fragment is most likely a sucrose synthase gene. BfSUS sequence shows the highest similarity with SUS genes of Tulipa gesneriana (80.6\%), followed by X. mokara (78.8\%), Potamogeton distinctus (78.7\%), Oncidium sp. $c v$ Goldiana (78.6\%), and Bambusa oldhamii (78.5\%).

Translation of BfSUS cDNA sequence resulted in BfSUS polypeptide sequence consists of 622 amino acids (Figure 5). The BLASTp program showed that BfSUS polypeptide sequence is highly similar with SUS protein sequences of many plant species, ranged from $78.3 \%$ to $87.5 \%$, confirming that the BfSUS gene expresses SUS protein. The highest similarity, $87.5 \%$, are showed by Tulipa gesneriana, a Liliaceae plant widely known as tulip, and Oncidium cv 'Goldiana', a genus that contains about 330 species of orchids from the Orchidaceae family. Oryza sativa (86.8\%), Bambusa oldhamii (86.5\%), Zea mays (86.2\%), and other monocots also showed high similarity.

In order to elucidate relationship between BfSUS putative protein and SUS proteins from other species, and between monocot and dicot species, a phylogenetic tree is generated using NeighborJoining method (Figure 6). The following things can be interpreted from the phylogenetic tree. First, the similarity of SUS polypeptide sequence in certain taxonomic group tends to be higher than another group. The similarity of SUS among monocot species, for instance, is distinctively higher than those of dicot species. This also showed by species coming from the same genus, for instance, between Solanum tuberosum and Solanum lycopersicum. Second, B. flabellifer is shown to be clustered with the monocot group, although not specifically grouped with particular monocot species. It is however shown that Borassus flabellifer has the nearest genetic distance with Tulipa gesneriana. Although these two species live in distinctively different climate regions, presumably they both evolve similar mechanism to adapt to osmotic stress in their surroundings, probably by accumulating sucrose. In water stress conditions, plants are able to keep their osmotic gradient lower than their surrounding by accumulating more solutes, including sucrose, in their tissues, thereby preventing loss of water.

Multiple sequence alignment of SUS polypeptides indicated two main domains that typically occurred in all plant species. Those are a sucrose synthase domain located upstream toward the $\mathrm{N}$-terminal and a glucosyltransferase domain that is located downstream towards the C-terminal 
of the protein. These domains differs SUS from other glycosyltransferase enzymes. Using pFam database, it was shown that those two domains are occurred in the BfSUS polypeptide albeit in partial length. The moiety of sucrose synthase and glucosyltransferase domain is found toward the $\mathrm{N}$ and C-terminal region, respectively, of the BfSUS polypeptide. The overlapped region between these domains is spanned from Asn283 to Ser559. Despite found to be highly conserved among plant species, the structural and functional sites and motifs within sucrose synthase domain are still unrevealed yet. Instead, four putative functional motifs have been reported for the second domain, the glycosyl transferase.

It is known that structure of a protein determine its function. Therefore, function of a protein could be deduced by comparing protein sequences and structures with homolog proteins of known function. Similar motifs between two proteins generally will have same function, especially when they are homolog (Horton et al., 2006). Functional motifs within the BfSUS polypeptide were elucidated by finding functional conserved motifs within other enzymes of GT family which had been previously annotated. Buschiazzo et al. (2004) had successfully isolated and crystallized another GT family enzyme from Agrobacterium tumefaciens, the Glycogen Synthase (GS). GS catalyses the synthesis of the $\alpha-1,4$-glucose backbone in the reaction of glycogen biosynthesis. This enzyme possesses the GT domain, a domain also found in SUS enzyme, with some annotated motifs within it. According to homolog motifs in GS (Buschiazzo et al., 2004), four functional motifs predicted as urasile diphosphate (UDP)-binding pockets were detected in the BfSUS polypeptide.

The first putative UDP binding pocket found in BfSUS polypeptide is Gly169, a residue located in a glycine rich motif, 166-DTGGQ-170 (Figure 7) (Huber and Huber, 1996; Buschiazzo et al., 2004). The Glycine $(\mathrm{G})$ residue is predicted to directly contact with phosphate group of UDP molecule that binds to SUS protein. Buschiazzo et al. (2004) discovered that, in the close conformation of the GS protein, the glycine residues in the KXGGL motif come into contact with the phosphate groups of UDP. This role had been reported also in the GS of Escherichia coli (Furukawa et al., 1993). They reported that only the glycine residues but not the basic side chain appear to be essential for GS enzymatic activity. The DTGGQ motif was found to be conserved in sucrose phosphate synthase (SPS), another member of GT family, which functioned as fructose-6-P binding site (Huber and Huber, 1996).

The three subsequent UDP-putative binding pockets in BfSUS polypeptide are 444-MAR-446 residues, N520, and T546 (Figure 8 and 9). It was observed that the MAR motif within the BfSUS polypeptide is located at the C-terminal end of a $\beta$-strand (Figure 8 ), a pattern that is also occurred in ISR motif of GS polypeptide, albeit in different number of $\beta$-strand. This probably reflects their similar role. It was observed that the guanidinium group of R299, in GS, interacts with the phosphate group of ADP via a hydrogen bonding (Buschiazzo et al., 2004). The MAR residues of BfSUS polypeptide thereby suggested as binding site for phosphate group of UDP via a hydrogen interaction. The Asn520 (N520) motif of BfSUS polypeptide is predicted to bind with the adenine ring of the UDP molecule. According to GS, the carbonyl group of protein backbone in Asn520 may be interacted with atom N6 of the adenine ring of UDP molecule via a weak hydrogen interaction. The last putative UDP binding pocket, the T546 was suggested to bind ribose sugar of UDP molecule. The side chain of T546 may interact via hydrogen bond with $\mathrm{O}_{2}$ atom of the ribose sugar.

The last conserved region of SUS protein that is also found in BfSUS polypeptide is the Ser170 putative phosphorylation site. This essential site was found within a typical serine residue containing- motif, 'RHLSS', which lay between Arg167 and Ser171. In the partial BfSUS polypeptide this motif is located between Arg30 and Ser34 (30-RHLSS-34). This motif was firstly detected in Zea mays SUS protein, spanned from Arg159 to Ser163 (Hardin et al., 2003). This motif was also found in Oryza sativa, Saccharum officinarum (R159 to S163), Bambusa 
oldhamii, Triticum aestivum (R167 to S171), and Tulipa gesneriana (R161 to S165). Hardin et al (2003) reported that SUS protein of Zea mays is phosphorylated by calcium-dependent protein kinases (CDPKs) at the Ser170 residue, within the RHLSS motif, in addition to Ser15 (Asano et al., 2002). Ser 15 was reported as a major phosphorylation site that affects cleavage activity and membrane association, whereas Ser170 is a minor phosphorylation site that may trigger enzyme degradation via the ubiquitin/26S proteasome (Qiu et al., 2007). Since phoshorylation of Ser170 is important for enzyme degradation but not directly involved in the catalytic activity of SUS, this site is suggested as one of the allosteric sites of the enzyme.

Those all results confirm that the isolated $1866 \mathrm{bp}$ of BfSUS gene fragment is most likely the sucrose synthase- encoding gene in B. flabellifer that encodes SUS protein. Further expression study however is required to prove that the BfSUS gene actually expresses sucrose synthase protein in B. flabellifer. The sequence of partial BfSUS has been submitted to the GenBank with accession number GQ265926.

\section{MATERIALS AND METHODS}

\section{Plant Material}

Young leaves were picked from the apical shoot of 35-40 years age-plant of Palmyra palm (Borassus flabellifer) grown in Lasiana shore area in Kupang, East Nusa Tenggara. Leaves samples were cleaned, wrapped, and immediately stored in cold condition before being taken to Bandung. The whole processes of sampling were done with RNase-free standard work procedure. Leaves samples were then frozen in liquid nitrogen and were stored in $-80^{\circ} \mathrm{C}$ refrigerator before RNA isolation. All the laboratory works took place in the Laboratory of Genetics and Molecular Biology, in SITH-ITB, Bandung.

\section{RNA Isolation}

Total RNA of B. flabellifer was extracted from the fresh young leaves that were previously stored in $-80^{\circ} \mathrm{C}$. All chemicals were diluted in RNAse-free water and prepared using RNAse-free equipments. All equipments were formerly treated with dietylpyrocarbonate (DEPC) before use. Grinding equipment, such as mortar, pestel, and scissors were chilled before use, either by storing in $-80^{\circ} \mathrm{C}$ or by soaking in liquid nitrogen.

Five protocols have been tested to optimize RNA isolation method from young leaves of $B$. flabellifer. Those are method of Seki et al. (2002), method of Khemvong and Suvachittanont (2005), modified-method of Apt et al. (1995), TRIzol-modified (I) method, and TRIzol modified (II) method (Invitrogen). Quality of RNA is determined by absorbance ratio in $260 \mathrm{~nm}$ and 280 nm UV light in the range of $1.80-2.00$ which indicated low contamination of protein. Appearance of two typical ribosomal RNA bands, $18 \mathrm{~s}$ and $28 \mathrm{~s}$, in electrophoresis gel also indicated good quality of RNA. The quantity of RNA was determined by RNA yield $(\mu \mathrm{g})$ per total solution volume (ml).

\section{Primer Design}

Sequence of $B$. flabellifer SUS gene is currently unavailable in the GenBank, thereby pair of primer was designed from highly conserved region of SUS proteins among monocot plant species. Sucrose synthase protein sequences of Oryza sativa, Zea mays, Saccharum officinarum, and other monocots, were accessed from NCBI GenBank database (www.ncbi.nlm.nih.gov). Multiple sequence alignment of SUS proteins was conducted using Clustal X software. The most conserved regions in SUS proteins among those species were chosen for primer sequence 
determination. Primer sequences were deduced from those regions by choosing a particular group of species whose cDNA sequence is highly conserved. This was accomplished by BioEdit and CodeHop programs. Nucleotide number 412 to 432 of SUS gene of Zea mays was chosen as forward primer; while reverse primer was taken from nucleotide number 2277 to 2252 . Primer physical characteristics were measured by sigma-genosys primer calculator. Specificity of both primer pairs were tested by nucleotide BLAST program (Altschul et al., 1997). The chosen primer sequences showed eligible characteristics, and more importantly, exhibited high specificity for SUS gene (Table 2).

\section{Reverse Transcription-PCR}

Isolation of sucrose synthase (SUS) gene from B. flabellifer was accomplished by two step reverse-transcription polymerase chain reaction (RT-PCR) method. In the first step, total cDNA is synthesized from the total RNA by using Superscript II cDNA synthesis kit (Invitrogen). In the second step, PCR amplification using SUS gene-specific primers was carried out to specifically amplify fragment of SUS gene from the previously isolated cDNA.

\section{Total cDNA synthesis}

Total cDNA synthesis of B. flabellifer was conducted using Superscript II cDNA synthesis kit (Invitrogen). Composition of each component in cDNA synthesis reaction is described in Table 3. All solutions are diluted in DEPC-treated deionized water. All steps were carried out according to RNAse-free standard work procedure to avoid or minimize degradation of the RNA.

A master mix solution was prepared by mixing buffer RT with $\mathrm{MgCl}_{2}$, Dithiothreitol (DTT), and RNase out ${ }^{\mathrm{TM}}$ recombinant RNase. Separately, RNA sample was mixed with oligo dT primer and dNTPs prior to five minutes incubation in $65^{\circ} \mathrm{C}$ and then one minute in ice. The master mix was then added to the RNA sample mixture and then diluted with DEPC-treated water to $20 \mu$ final volume. This final mixture was incubated for two minutes in $42^{\circ} \mathrm{C}$ for primer annealing. Superscript $^{\mathrm{TM}}$ II- Reverse Transcriptase was subsequently added to the mixture, gently homogenized, and then incubated for 50 minutes in $42^{\circ} \mathrm{C}$ for complete reaction of cDNA synthesis. The reaction was terminated by 15 minutes incubation in $70^{\circ} \mathrm{C}$. To eliminate any remaining RNA strands in the cDNA solution, RNaseH were added to the solution and then incubated in $37^{\circ} \mathrm{C}$ for 20 minutes. Total cDNA of B. flabellifer young leaves was obtained at the end of this step.

\section{PCR Amplification for Isolation of SUS gene}

A standard PCR amplification technique was conducted following the cDNA synthesis to specifically isolate the SUS gene. Optimization of PCR profile, especially annealing temperature, was carried out to find the best condition that favor specific amplification of the SUS gene fragment. A range of annealing temperature, from $45^{\circ} \mathrm{C}$ to $55^{\circ} \mathrm{C}$, was tested. Concentration of cDNA template, ranging from 0.5 to $2 \mu \mathrm{g} / 50 \mu \mathrm{l}$, and $\mathrm{Mg}^{2+}$, ranging from 1 to $2.5 \mathrm{mM}$, were tested as well to obtain best fragment of the target gene. The PCR reaction was carried out using a Long PCR Enzyme Mix product (FERMENTAS). Composition of the PCR mixture is described in Table 4.

\section{Gene Cloning and Transformation of $E$. coli}

The product of RT-PCR was observed by electrophoresis using $1 \%$ agarose gel. Detected SUS fragment was purified from the agarose gel and then cloned to the pGEM-T Easy ${ }^{\circledR}$ vector by employing T4 ligase enzyme. To amplify the SUS fragment, the recombinant plasmids were subsequently delivered into bacterial cell of Escherichia coli strain DH5 $\alpha$ using heat-shock 
treatment. The transformed cells of $E$. coli that contain recombinant plasmid were selected through screening of blue-white colony. The transformed cells were cultured for 16 hours in Luria-Bertany (LB) media containing $0.1 \mathrm{ng} / \mu \mathrm{l}$ ampicillin. The plasmids DNA of the transformed cells were then extracted by alkaline lysis method (Sambrook et al., 1989). Insertion of SUS fragment into plasmid was confirmed by cutting the plasmid with two endonuclease restriction enzymes, EcoRI and NotI.

\section{Sequencing and Characterization of BfSUS Gene and Polypeptide}

SUS putative fragment that have been cloned to pGEM-T easy plasmid were further analyzed by dideoxy chain-termination method to read the nucleotide sequence of the isolated fragment. Minimum $150 \mathrm{ng} / \mu \mathrm{l}$ of plasmid DNA is required to a single sequencing reaction. Since the 1866 bp gene fragment is relatively long for a single accurate reading by the sequencer system, two steps of sequencing are needed to accomplish the total fragment reading. The first sequencing employed T7 and SP6 universal primers, which followed by second sequencing using gene internal-primers. Gene-internal primers were designed from the first sequencing result. Sequencing result from those four primer directions were finally assembled using Geneious 4.6.2 program. All sequencing process was conducted by Macrogen Inc. in South Korea.

Characterization of BfSUS putative gene comprises nucleotide and polypeptide sequence analysis. The nucleotide sequence of the putative BfSUS was aligned with SUS cDNA sequences deposited in GenBank (www.ncbi.nlm.nih.gov) using BLASTn program in order to find their similarity. The BfSUS cDNA sequence was then translated into BfSUS polypeptide using Geneious 4.6.2, followed by searching in the GenBank using BLASTp program. The highly conserved regions, including essential domains and motifs, were searched within BfSUS putative polypeptide, either by employing Geneious 4.6.2 program or by comparing the polypeptide with other related proteins that have been previously annotated. Other proteins from the same family are preferable since it is expected to share similar properties with the SUS. To reveal genetic relationship between Borassus flabellifer and other plant species based on their SUS polypeptide sequence, a neighbor- joining (NJ) phylogenetic tree was generated using Geneious 4.6.2 tree builder.

\section{CONCLUSION}

A partial cDNA fragment of sucrose synthase (SUS) putative gene has been successfully isolated from the young leaves of B. flabellifer, henceforth named as BfSUS. The sequence has been submitted to the Genbank with accession number GQ265926. The sequence of BfSUS cDNA, and the corresponding BfSUS polypeptide, is highly similar with SUS cDNA and SUS protein from various plant species recorded in GenBank, with highest similarity shown by Tulipa gesneriana and Oncidium sp. The BfSUS putative polypeptide performs all typical characteristics of SUS protein, including most conserved domains and motifs. Presence of sucrose synthase (SUS) and glycosyl transferase (GT) domains, four putative UDP-glucose binding pockets within the GT domain, and a calcium-dependent Ser/Thr protein kinase binding site (Ser170) within the SUS domain, confirms that the BfSUS cDNA fragment obtained in this study is most likely encodes sucrose synthase in B. flabellifer. This also assuring that BfSUS gene is expressed in the young leaves of $B$. flabellifer. 
Table 1. Summary of five tested methods for RNA isolation from young leaves of $B$. flabellifer. TRIzol- modified II found to be the best method for RNA isolation from the young leaves of B. flabellifer

\begin{tabular}{|c|c|c|c|c|}
\hline Method & $\begin{array}{l}\text { Ratio of UV } \\
\text { absorbance } \\
\left(\mathrm{A}_{260} / \mathrm{A}_{280}\right)\end{array}$ & $\begin{array}{l}\text { RNA quality } \\
\text { in gel } \\
\text { electrophoresis }\end{array}$ & $\begin{array}{l}\text { RNA yield } \\
\left.(\mu \mathrm{g} / \mathrm{ml})^{*}\right)\end{array}$ & $\begin{array}{l}\text { Total } \\
\text { time } \\
\text { (hour) }\end{array}$ \\
\hline $\begin{array}{l}\text { TRIzol-modified I } \\
\text { (Invitrogen) }\end{array}$ & $1.23-1.24$ & Average & 114.75 & 5 \\
\hline Seki et al., 2002 & $1.44-1.47$ & Poor & 93.50 & 8 \\
\hline $\begin{array}{l}\text { Khemvong \& Suvachittanont } \\
\text { (2005) }\end{array}$ & $1.67-2.00$ & Poor & 44.625 & 12 \\
\hline Apt et al. (1995)-modified & $1.45-1.47$ & Good & 148.75 & 18 \\
\hline $\begin{array}{l}\text { TRIzol-modified II } \\
\text { (Invitrogen) }\end{array}$ & $1.61-1.62$ & Good & 1600 & 4 \\
\hline
\end{tabular}

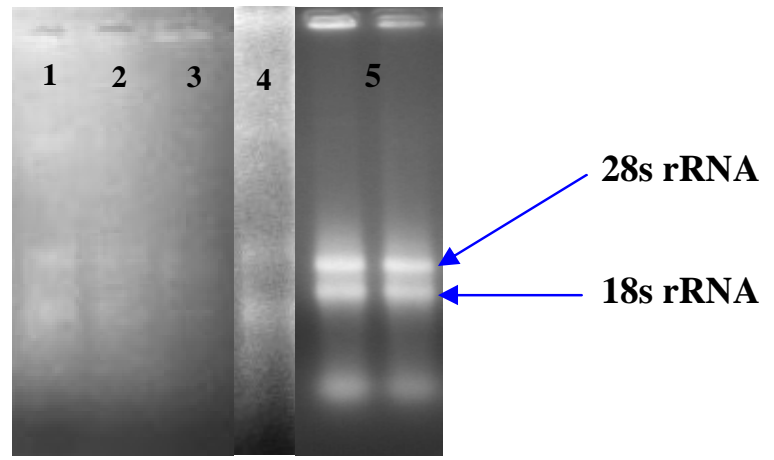

Figure 1. Comparison of RNA quality obtained by the five tested methods. Two bands of ribosomal RNA, the 18s and 28s rRNA, that were occurred in electrophoresis gel indicated that total RNA of B. flabellifer has been successfully obtained. TRIzol-modified II method is the best method for RNA isolation from the young leaves of $B$. flabellifer.

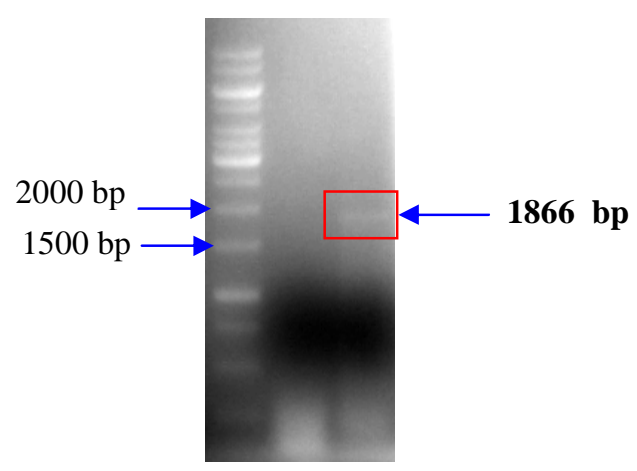

Figure 2. A single cDNA fragment of $1866 \mathrm{bp}$, generated by reverse transcription-PCR, predicted as the target fragment of the SUS gene of B. flabellifer. 

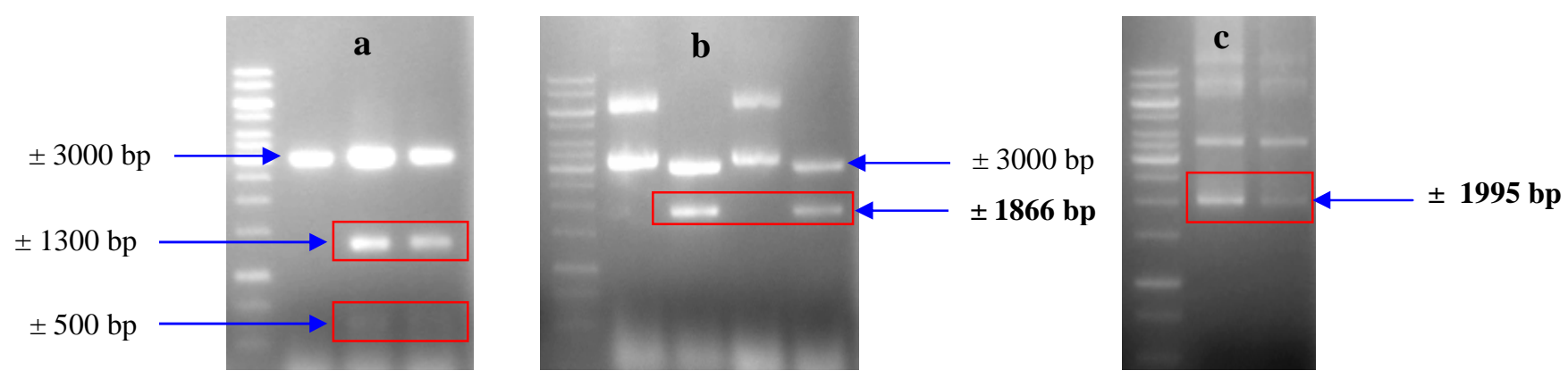

Figure 3. (a) The recombinant plasmid cut with EcoRI generated two unexpected \pm 1300 and \pm $500 \mathrm{bp}$ fragments indicating gene internal cut by this enzyme; (b) plasmid cut with NotI generated a single expected fragment of length $\pm 1866 \mathrm{bp}$, indicating that SUS gene of $B$. flabellifer had been successfully inserted in the MCS region of the plasmid; (c) PCR screening using SP6 and T7 primers resulted in \pm 1995 bp fragment confirmed the presence of SUS fragment within the MCS region of the pGEM $^{\circledR}$-T easy plasmid.

Table 2. Pair of forward and reverse primers used to isolate sucrose synthase gene from total RNA of Borassus flabellifer young leaves.

\begin{tabular}{|c|c|c|c|c|c|c|c|c|}
\hline $\begin{array}{l}\text { Primer } \\
\text { Code }\end{array}$ & Primer Sequence & Start & $\begin{array}{l}\text { Primer } \\
\text { Length }\end{array}$ & $\begin{array}{l}\text { Product } \\
\text { Size } \\
\text { (bp) }\end{array}$ & $\begin{array}{c}\text { GC } \\
(\%)\end{array}$ & $\begin{array}{l}\mathbf{T m} \\
\left({ }^{\circ} \mathbf{C}\right)\end{array}$ & $\begin{array}{l}\text { Sec. } \\
\text { Struc } \\
\text { ture }\end{array}$ & $\begin{array}{c}\text { BLAST } \\
\text { Output } \\
(\Sigma \\
\text { species })\end{array}$ \\
\hline SUSFw & CTTGAGCTGGACTTTGAGCCA & 412 & 21 & & 52.38 & 62.92 & Weak & 10 \\
\hline SUSRv & $\begin{array}{l}\text { CTTCCAGGTGTACTTCTCCTCGAT } \\
\text { AC }\end{array}$ & 2277 & 26 & 1866 & 50.00 & 62.72 & Weak & 8 \\
\hline
\end{tabular}

Table 3. Chemical composition in cDNA synthesis

\begin{tabular}{clc}
\hline No. & \multicolumn{1}{c}{ Component } & Final concentration \\
\hline 1 & Total RNA of $B$. flabellifer & $2 \mu \mathrm{g} / 20 \mu \mathrm{l}$ \\
2 & dNTPs & $0.5 \mathrm{Mm}$ \\
3 & Oligo (dT) ${ }_{12-18}$ primer & $0.025 \mu \mathrm{g} / \mu \mathrm{l}$ \\
4 & Buffer RT & $1 \mathrm{x}$ \\
5 & $\mathrm{MgCl}_{2}$ & $5 \mathrm{mM}$ \\
6 & Dithiothreitol (DTT) $_{7}$ & $0.01 \mathrm{M}$ \\
7 & RNase out $^{\mathrm{TM}}$ Recombinant Rnase & $1 \mathrm{u} / 20 \mu \mathrm{l}$ \\
8 & Superscript $^{\mathrm{TM}}$ II- Reverse Transcriptase & $1 \mathrm{u} / 20 \mu \mathrm{l}$ \\
9 & DEPC-treated deionized water & until $20 \mu \mathrm{l}$ \\
10 & E. coli RNaseH & $1 \mu \mathrm{l} / 20 \mu \mathrm{l}$ \\
\hline
\end{tabular}

Table 4. Composition of PCR mixture for SUS cDNA isolation

\begin{tabular}{clc}
\hline No. & \multicolumn{1}{c}{ Component } & Final concentration \\
\hline 1 & $10 \mathrm{x}$ long PCR buffer & $1 \mathrm{x}$ \\
2 & $2 \mathrm{mM} \mathrm{dNTP} \mathrm{mix}$ & $0.2 \mathrm{mM}$ \\
3 & $25 \mathrm{mM} \mathrm{MgCl}$ & $2 \mathrm{mM}$ \\
4 & Primer (forward and reverse) & $0.2 \mu \mathrm{M}$ \\
5 & Total cDNA & $0.03 \mu \mathrm{g} / \mu \mathrm{l}$ \\
6 & Long PCR enzyme mix & $1.25 \mathrm{unit} / 50 \mu \mathrm{l}$ \\
7 & Nuclease free water & to $25 \mu \mathrm{l}$ \\
\hline
\end{tabular}




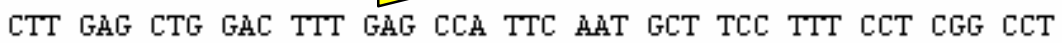
Leu Glu Led Asp Phe Glu Pro Phe han hla ser Phe Pro hrg Pro

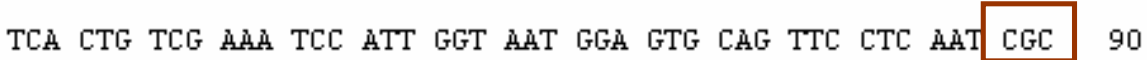

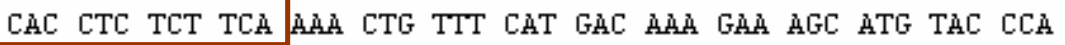

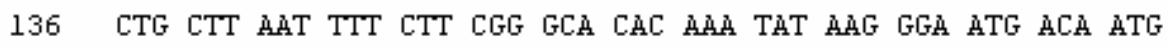

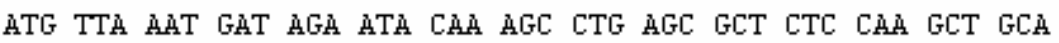

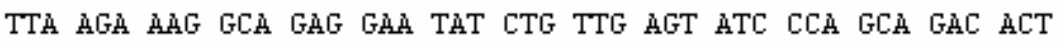

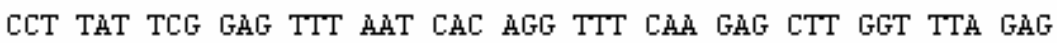

Ä̈G GGT TGG GGT GAT ACA GCT CAG CGT GTT GGT GḦG ACT ATT CAT

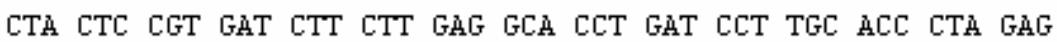

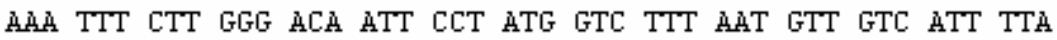
Lys Phe Leu Gly Thr Ile fro Met Val phe han Val Val Ile Leu

451 TCT CCA CAL GGT TÁ TTT GCC CÄ GCT AूT GTT TTG GGÄ TAC CCT

151 Ser Pro His GlY TYr Fhe Ala Gln Ala Asn Val Leu Gly Tyr fro

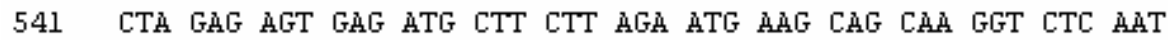

181 Leu Glu ser Glu Met Leu Leu hrg Met Lys Gln Gln Gly Leu Asn

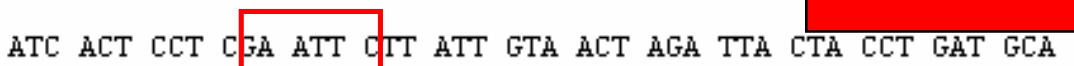
Ile Thr pro hrg Ile Leu Ile Val Thr hrg Leu Leu Pro Aap Ala ДTT GGG HCC ДCT TGC GGT CAG CGG CTT GAG AДA GTC CTA GGC ACA Ile Gly Thr Thr CYs Gly Gln Arg Leu Glu LYs Val Leu Gly Thr

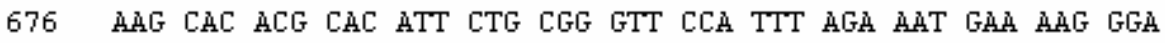
LYs His Thr His Ile Leu Arg Val pro Phe Arg Asn Glu LYs GlY 241 Ile Leu hro Lyo Trp Ile ser hrg ser hsp Val Trp fro TYr Leu

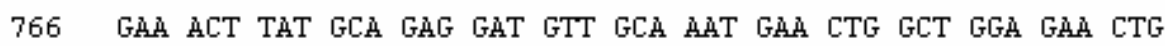
256 Glu Thr TYr hla Glu Asp Val Ala Asn Glu Leu Ala Gly Glu Leu

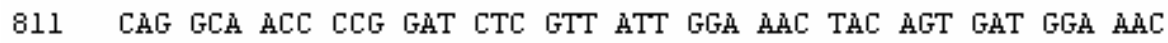
271 Gln hla Thr Pro hap Leu Val Ile Gly Aan TYr Ser Asp Gly Aan

856 CTA GTA GCA TCT TTG TTG GCA CAT मдд CCA GGG GTT ACT CAG TGT 286 Leu Val hla Ser Leu Leu hla His LYs Pro Gly Val Thr Gln Cys

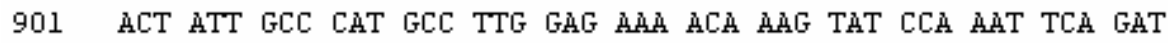
301
135

45

180

60

225

75

270

90

315

10.5

360

120

40.5

135

450

1.50

495

16.5

540

180

585

195

630

210

675

22.5

720

240

765

25.5

810

270

855

285

900

300

94.5

31.5 


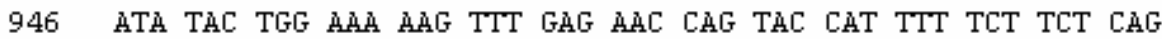

316 Ile TYr Trp LYs LYs the Glu Asn Gln TYr His the Ser ser Gln

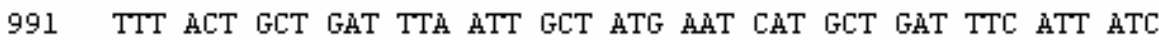
330

331 Phe Thr Ala Asp Leu Ile Ala Met Asn His Ala Asp Phe Ile Ile

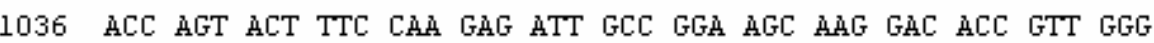
345

346 Thr ser Thr the Gln Glu Ile dla Gly ser LYs dap Thr Val Gly

1081 CÄG TALC GAG TCT CAL ATT GCA TTT ACC CTC CCT GGG CTC TAC CGA 360

361 Gln Tyr Glu ser His Ile dia the Thr Leu Pro Gly Leu Tyr arg

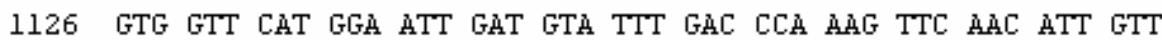
375

376 Tal Tal His Gly Ile Asp Val Phe Asp Pro LYs Phe Asn Ile Val

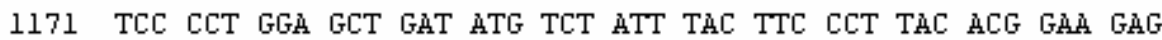
390

391 Ser Pro Gly dila hsp Met Ser Ile TYr Phe Pro TYr Thr Glu Glu

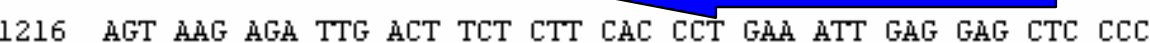
40.5

406 Ser Lys àrg Leu Thr ser Leu His Fro glu Ile Glu glu Leu Fro

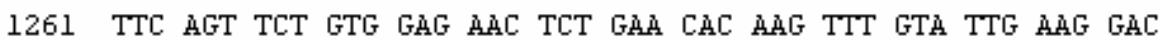

421 The ser ser Val Glu Asn ser Glu His Lys the Tal Leu Lys hsp

420

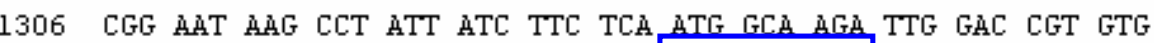
436 Arg Asn LYs Pro Ile Ile Phe ser Met Ala Arg Leu Asp Arg tal

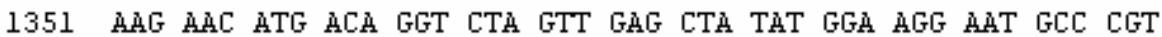
4.51 LYs han Met Thr Gly Leu Val Glu Leu Tyr Gly hrg Asn Ala hrg

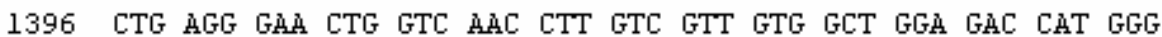
466 Leu hro Glu Leu Val Asn Leu Val Val Wal hla GlY ḣs His Gly

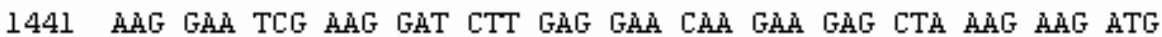
461 Lys Glu Ser LYs hap Leu Glu Glu Gln Glu Glu Leu LYs LYs Met

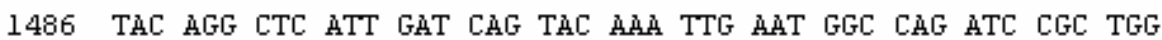
496 Tyr Arg Leu Ile Asp Gln TYx LYs Leu Asn Gly Gln Ile hrg Trp

1531 ATC TCT GCC CAG ATG AAC AGG GTT CGC AAT GGT GAG CTA TAC CGC

511 Ile Ser hla Gln Met Asn arg Val Arg han GlY Glu Leu TYr Arg

1576 TAL ATT GCC GAT ACC GGÄ GGÄ GCC TTT GTT CAG CCG GCA TTT TÄT

526 TYr Ile Ala Asp Thr GlY GlY dla Phe Val Gln Pro dla Phe TYr

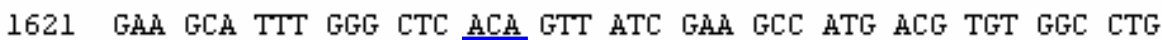
541 Glu dla phe GlY Leu Thr Val Ile Glu hla Met Thr CYs Gly Leu

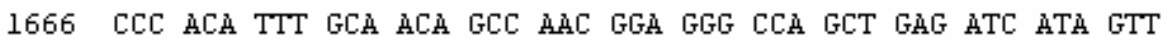




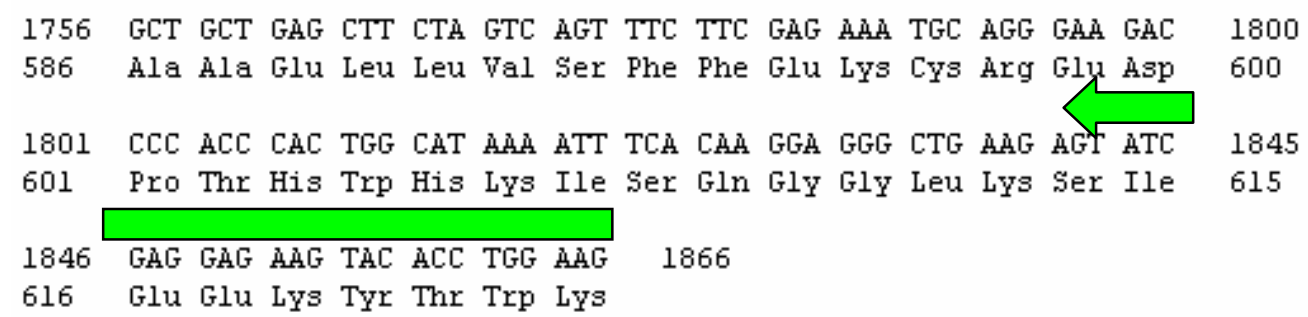

Figure 4. Sequence of partial cDNA of Borassus flabellifer SUS putative gene. The yellow arrow indicates forward primer, SSFw, and the green arrow indicates reverse primer, SSRv. The red arrow indicates internal primer $\mathrm{p} 1$, and the blue arrow indicates internal primer p2. The red box indicates restriction site of EcoRI endonuclease restriction enzyme. The brown box indicates putative phosphorylation site (30-RHLSS34). The blue boxes indicate four putative UDP binding pockets (166-DTGGQ-170; 444MAR-446; N520; and T546)

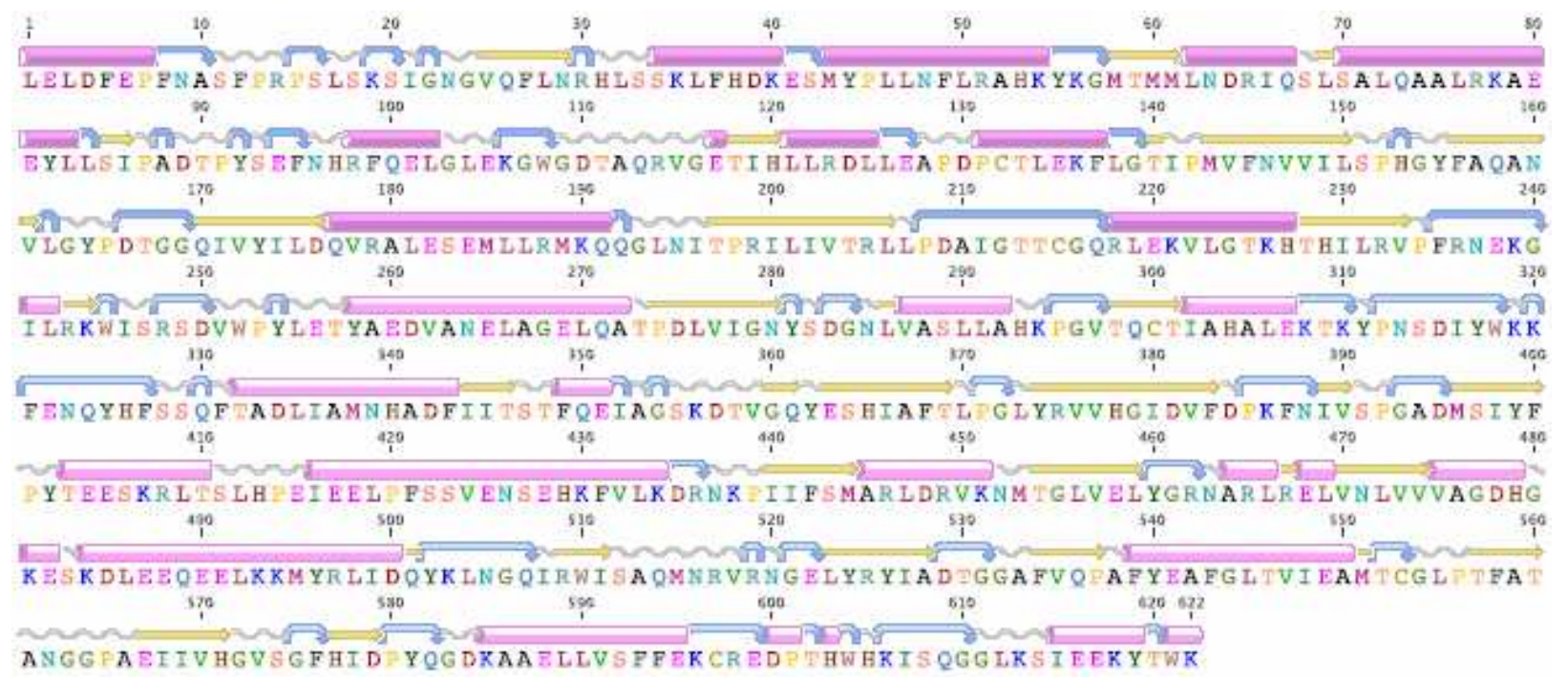

Figure 5. The BfSUS putative polypeptide sequence with total length 622 amino acids was generated by translating the sequence of BfSUS cDNA, using Geneious 4.6.2. 


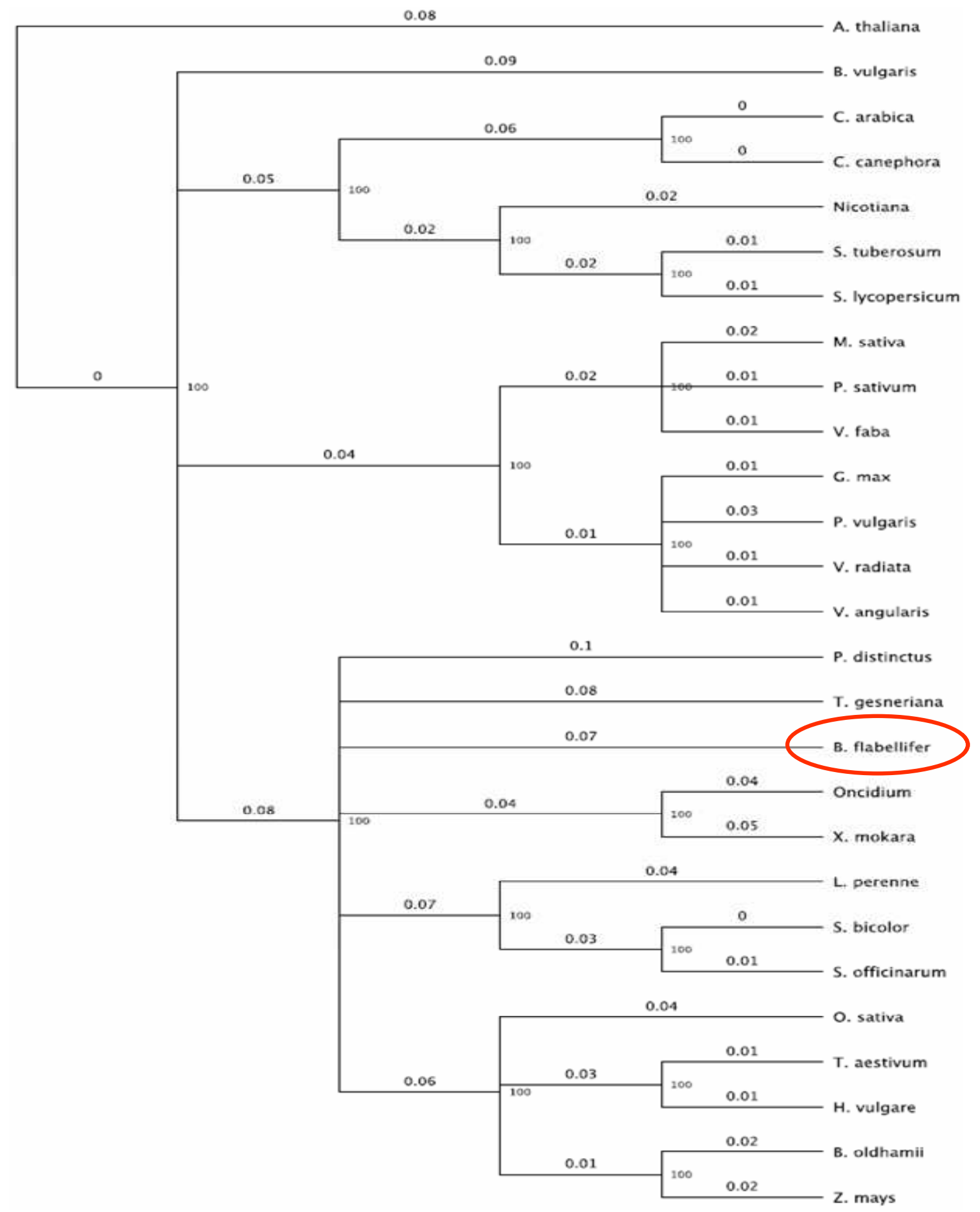

Figure 6. A phylogenetic tree based on sucrose synthase polypeptide sequence of various monocot and dicot species. Similarity of SUS polypeptide among monocot species is distinctively higher than those of dicot species. Borassus flabellifer is clustered with the monocot group, although not specifically grouped with particular monocot species. B. flabellifer showed the nearest genetic distance with Tulipa gesneriana. 


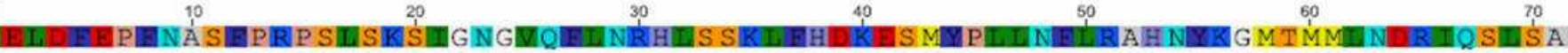

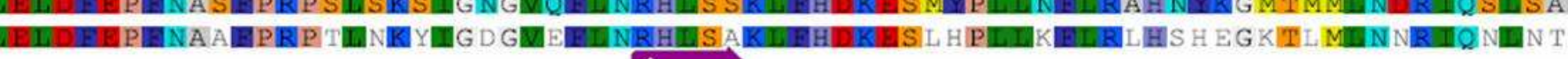
Sucrose synth T

RHLSS motif put phosphorylation site

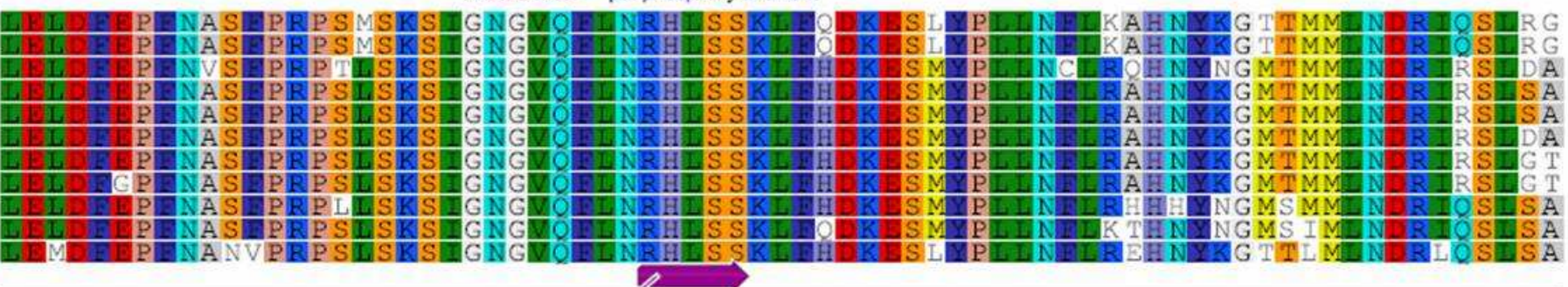

Sucrose synth ग

RHLSS motf put phosphorylation site

B. flabellifer

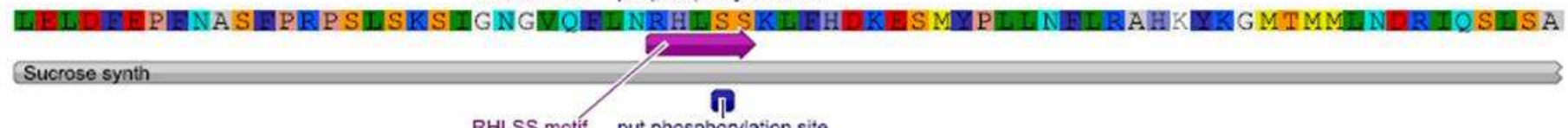

RHLSS motif put phosphoryion site

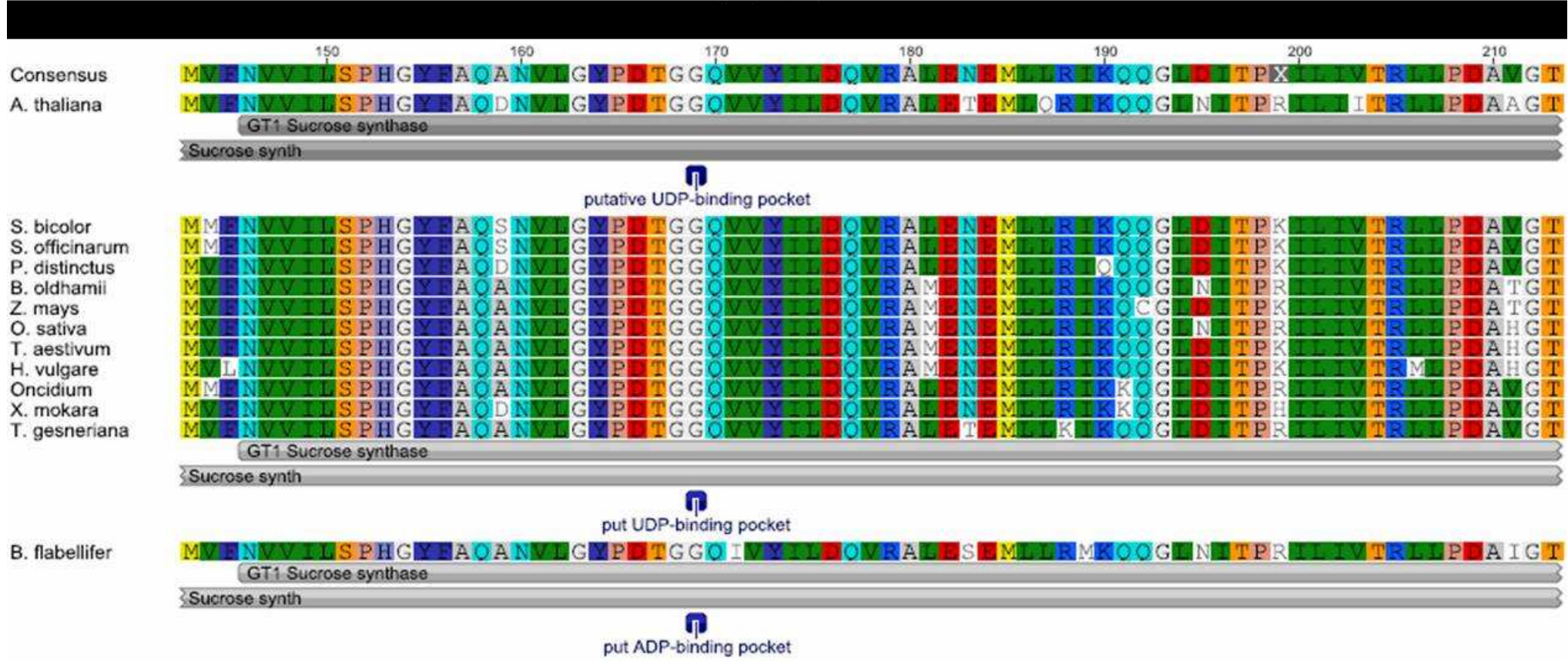

Figure 7. Seven regions in BfSUS polypeptide that highly conserved among monocot species: (1) Sucrose synthase domain spanning from Nterminal region to Ser422; (2) A putative calcium-dependent Ser/Thr protein kinase binding site in the 30-RHLSS-34 motif within the SUS domain. This site may have role in triggering enzyme degradation via the ubiquitin/26S proteasome; (3)Glycosyltransferase (GT) domain spanning from Asn146 to the C-terminal region. Four putative UDP-binding pockets are detected within this domain. They are: (4) Glycine residues in 166DTGGQ-170 motif, (5) 444MAR446, (6) N520, and (7) T546. 


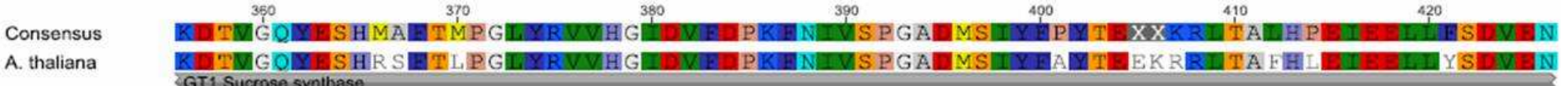
GT1 Sucrose synthas:

Sucrose synth

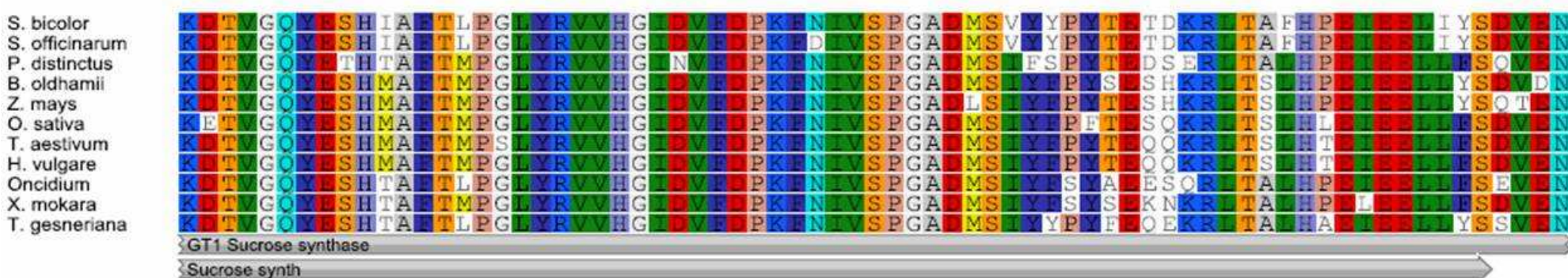

B. flabellifer

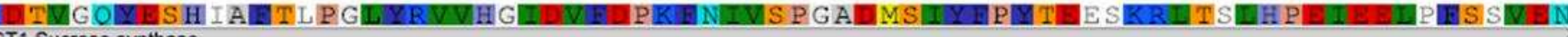
Gri sucrose synthas

Sucrose synth

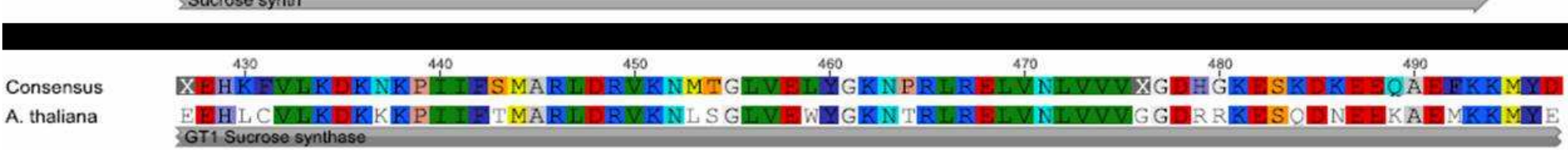

A. thaliana GTI Sucrose synthase

UDP-bindi

S. bicolor
S. officinarum

P. distinctus

B. oldham

Z. mays

T. aestivum

T. aestivum

H. vulgare
Oncidium

X. mokara

T. gesneriana

B. flabellifer

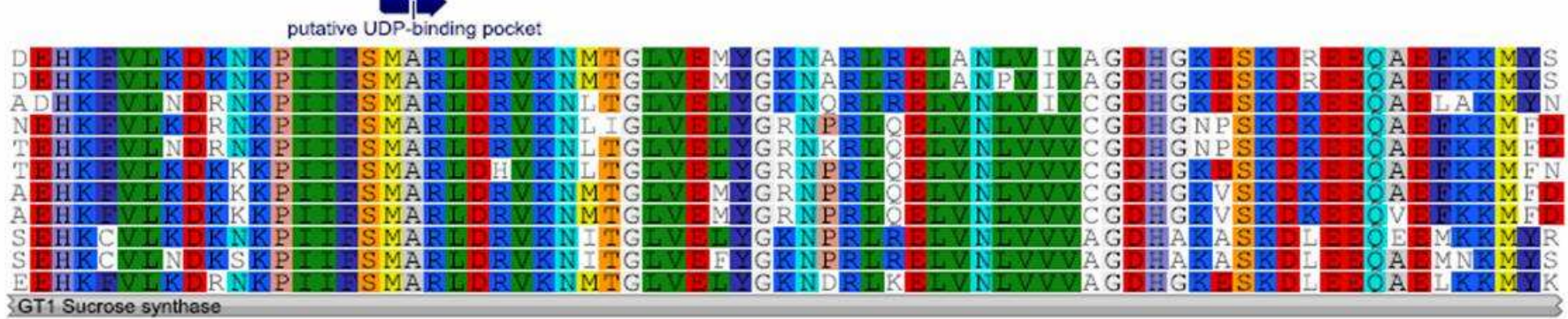

put UDP-binding pocket

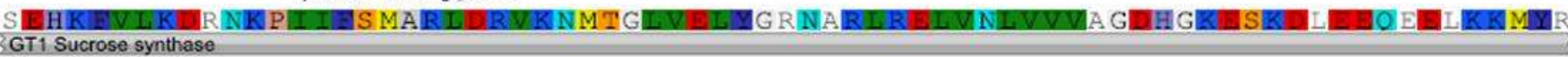

$\Rightarrow$

put UDP-binding pocket

Figure 8. Seven regions in BfSUS polypeptide that highly conserved among monocot species: (1) Sucrose synthase domain spanning from Nterminal region to Ser422; (2) A putative calcium-dependent Ser/Thr protein kinase binding site in the 30-RHLSS-34 motif within the SUS domain This site may have role in triggering enzyme degradation via the ubiquitin/26S proteasome; (3)Glycosyltransferase (GT) domain spanning from Asn146 to the C-terminal region. Four putative UDP-binding pockets are detected within this domain. They are: (4) Glycine residues in 166DTGGQ-170 motif, (5) 444MAR446, (6) N520, and (7) T546. 
n

putative UDP-binding pocket $\boldsymbol{n}$

putative UDP-binding pocket

S. officinarum

P. distinctus
B. oldhamii

Z. mays

O. sativa

T. aestivum
H. vulgare

H. vulgare
Oncidium

X. mokara
T. gesnerian

T. gesneriana

B. flabellifer

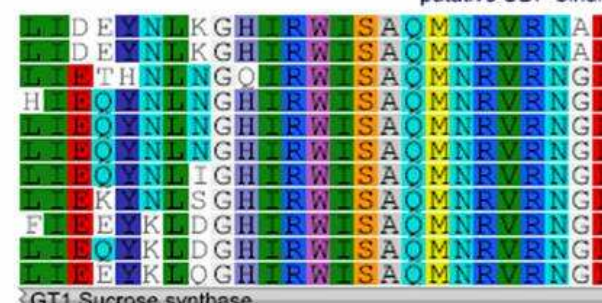

GTI Sucrose synthase
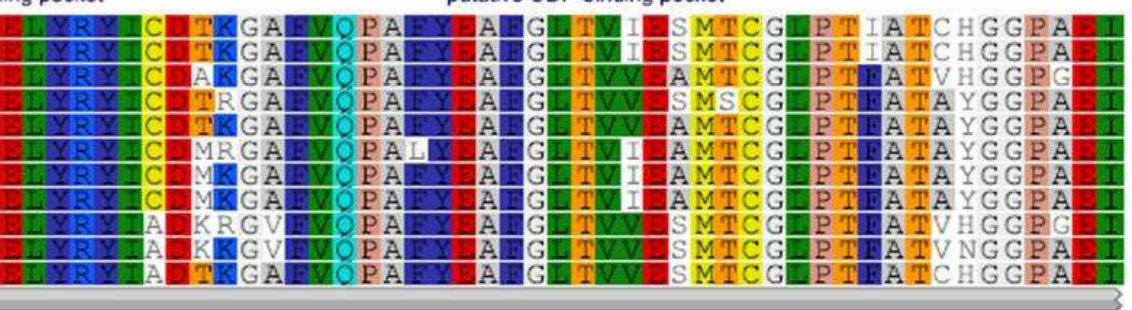

$\prod_{\text {put UDP-binding pocket }}$

T

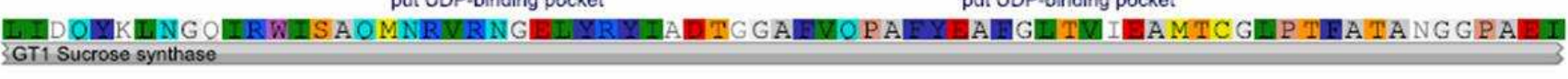

put UDP.binding pocket

T

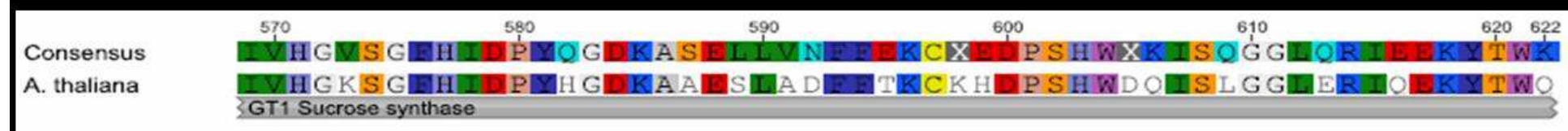

S. bicolor

S. officinarum

P. distinctus

Z. mays

O. sativa

T. aestivum

Oncidium

$X$. mokara

T. gesneriana

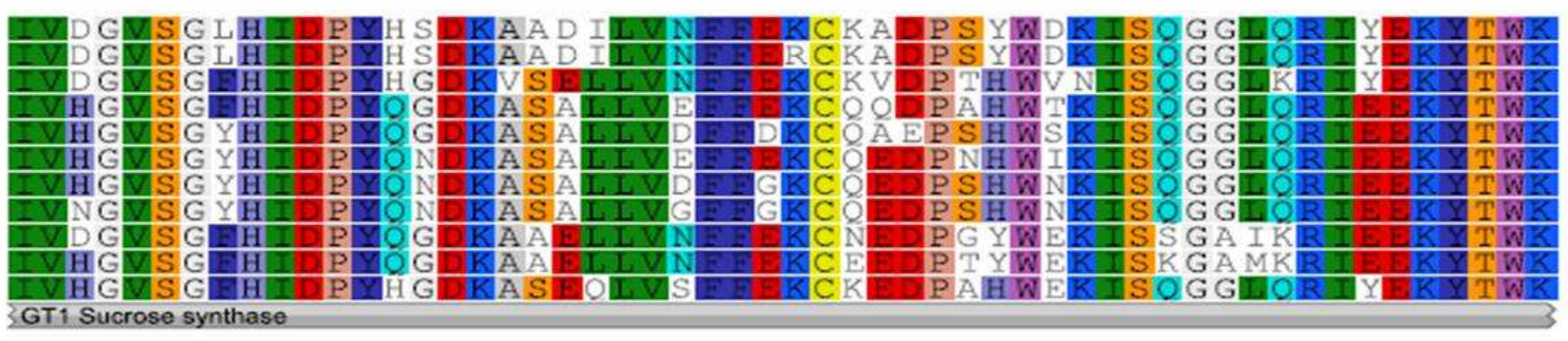

B. flabellifer

IVHGVS GEHIDPYOGDKAAELLVS

EFEKC

CREP THWHIK IS O G GLK S

YTWK

Figure 9. Seven regions in BfSUS polypeptide that highly conserved among monocot species: (1) Sucrose synthase domain spanning from Nterminal region to Ser422; (2) A putative calcium-dependent Ser/Thr protein kinase binding site in the 30-RHLSS-34 motif within the SUS domain. This site may have role in triggering enzyme degradation via the ubiquitin/26S proteasome; (3)Glycosyltransferase (GT) domain spanning from Asn146 to the C-terminal region. Four putative UDP-binding pockets are detected within this domain. They are: (4) Glycine residues in 166DTGGQ-170 motif, (5) 444MAR446, (6) N520, and (7) T546. 


\section{ACKNOWLEDGEMENT}

We thank the Southeast Asian Organization of Tropical Biology (SEAMEO-BIOTROP) for funding this research. Our work has been supported by a research grant form SEAMEO-BIOTROP in the period of 2008-2009. Our gratitude to the School of Life Sciences and Technology for the facilities we were able to use in the Laboratory of Genetics and Molecular Biology. Thanks to Mikael Tupa for his favor in obtaining the Borassus flabellifer leaves in Lasiana coastal area. We also thank Dr. Suminar Achmadi and the BIOTROPIA reviewers for their careful reading, comments, and corrections of the manuscript.

\section{REFERENCES}

Altschul, Stephen F., Thomas L. Madden, Alejandro A. Schäffer, Jinghui Zhang, Zheng Zhang, Webb Miller, and David J. Lipman. (1997). Gapped BLAST and PSI-BLAST: a new generation of protein database search programs. Nucleic Acids Res. 25:3389-3402.

Apt, KE., Clendennen, SK., Powers, DA., Grossman, AR. (1995). The gene family encoding the fucoxanthin chlorophyll proteins from the brown alga Macrocystis pyrifera. Mol. Gen. Genet. 246: 455-464.

Baud, S., Vaultier, M.N., Rochat, C. (2004). Structure and expression profile of the sucrose synthase multigene family in Arabidopsis. Journal of Experimental Botany. 55 (396): 397-409.

Bush, D. (1999). Sugar transporters in plant biology. Curr. Opinion in Plant Biology 2:187-191.

Buschiazzo, Alejandro, Juan Ugalde, Marcelo Guerin, William Shepard, Rodolfo Ugalde, Pedro Alzari. (2004). Crystal structure of glycogen synthase: Homologous enzymes catalyze glycogen synthesis and degradation. The EMBO Journal. 23: 3196-3205

Carlson, S.J, Chourey, P.S. (1996). Evidence for plasma membrane-associated forms of sucrose synthase in maize. Molecular Genome Genetics 252: 303-310.

Chomczynski, P., Sacchi, N. (1987). Single-step method of RNA isolation by acid guanidinium thiocyanatephenol-chloroform extraction. Anal. Biochem. 162: 156-159

Craig, J., Barratt, P., Tatge, H., Dejardin, A., Gardner, C. D., Barber, L., Wang, T. L., Hedley, C. L., Martin, C., Smith, A.M. (1999). Mutations at the rug4 locus alter the carbon and nitrogen metabolism of pea plants through an effect on sucrose synthase. The Plant Journal. 17: 353-362.

D’Aoust, Marc-Andre, Serge Yelle, Binh Nguyen-Quoc. (1999). Antisense Inhibition of Tomato Fruit Sucrose Synthase Decreases Fruit Setting and the Sucrose Unloading Capacity of Young Fruit. The Plant Cell. 11: 2407-2418.

Dejardin, A., Rochat, C., Wuilleme, S., Boutin, J.P. (1997). Contribution of sucrose synthase, ADP-glucose pyrophosphorylase and starch synthase to starch synthesis in developing pea seeds. Plant, Cell, and Environment. 20: 1421-1430.

Flach, M., F. Rumawas. (1996). Plant Resources of South-East Asia: Plants yielding non-seed carbohydrates. PROSEA. Bogor.

Fox, James. (1977). Harvest of the Palm: Ecological Change in Eastern Indonesia. University Press. Harvard.

Furukawa, K., Tagaya, M., Tanizawa, K., Fukui, T. (1993). Role of the conserved Lys-X-Gly-Gly sequence at the ADP-glucose-binding-site in Escherichia coli glycogen synthase. J Biol Chem 268: 2383723842.

Hardin, S.C., Tang, G.Q., Scholz, A., Holtgraewe, D., Winter, H., Huber, S.C. (2003). Phosphorylation of sucrose synthase at serine 170: occurrence and possible role as a signal for proteolysis. Plant $J$ 35: 588-603.

Huber, S.C., Huber, J.L. (1996). Role and regulation of sucrose-phosphate synthase in higher plants. Annu. Rev. Plant Physiol. Plant Mol. Biol. 47: 431-444.

Khemvong, S., Suvachittanont, W. (2005). Molecular cloning and expression of cDNA encoding 1-deoxy-Dxylulose-5-phosphate synthase from oil pal Elaeis guineensis Jacq. Plant Science. 169: 571-578.

Komatsu, Akira, Takaya Moriguchi, Kazuhiko Koyama, Mitsuo Omura, Tomoya Akihama. (2002). Analysis of Sucrose Synthase Genes in Citrus Suggests Different Roles and Phylogenetic Relationships. Journal of Experimental Botany. 53 (366): 61-71.

Kumar, A. S, P. H. Mooer, A. Maretzki. (2007). Amplification and Cloning of Sugarcane Sucrose Synthase cDNA by Anchored PCR. Cold Spring Harbor Laboratory 2: 70-75.

Lodish, H., Berk, A., Matsudaira, P., Zipursky, S.L., Darnell, J. Kaiser, C.A., Krieger, M., Scott, M.P. (2004). Molecular Cell Biology $5^{\text {th }}$ Edition. Gordonsville: W H Freeman. 
Marana, C., Garcia-Olmeda, F., Carbonero, P. (1988). Linked sucrose synthase genes in group-7 chromosomes in hexaploid wheat (Triticum aestivum L.). Gene 63: 253-260.

McCarty, D.R., Shaw, J.R. Hannah, L.C. (1986). The cloning, genetic mapping, and expression of the constitutive sucrose synthase locus of maize. Proc. Natl Acad. Sci. 83: 9099-9103.

Ruan, Y. L.; D.J. Llewellyn; R. T. Furbank. (2003). Suppression of Sucrose Synthase Gene Expression Represses Cotton Fiber Cell Initiation, Elongation, and Seed Development. The Plant Cell 15: $952-$ 964.

Sambrook, J., Fritsch, E.F., Maniatis, T. (1989). Molecular Cloning A Laboratory Manual 2nd edition, New York: Cold Spring Harbor Laboratory Press.

Seki M., Narusaka M., Ishida J., Nanjo T., Fujita M., Oono Y., Kamiya A., Nakajima M., Enju A., Sakurai T., Satou M., Akiyama K., Taji T., Yamaguchi-Shinozaki K., Carninci P., Kawai J., Hayashizaki Y.. and Shinozaki K. (2002). Monitoring the expression profiles of 7000 Arabidopsis genes under drought, cold and high-salinity stresses using a full-length cDNA microarray. Plant Journal 31: 279292. 